\section{Reviving Chickpea Production in Nepal Through Integrated Crop Management, with Emphasis on Botrytis Gray Mold}

\section{S. Pande}

International Crops Research

Institute for the Semi-Arid Tropics,

Patancheru 502 324,

Andhra Pradesh, India

\section{P. Stevenson}

Natural Resources Institute,

University of Greenwich,

Kent ME4 4TB, United Kingdom

\section{J. Narayana Rao}

International Crops Research Institute for the Semi-Arid Tropics,

Patancheru, 502324

Andhra Pradesh, India

\section{R. K. Neupane}

and R. N. Chaudhary

Nepal Agricultural Research Council,

P.O. Box 5459, Kathmandu, Nepal

\section{Grzywacz}

Natural Resources Institute,

University of Greenwich,

Kent ME4 4TB, United Kingdom

\section{A. Bourai}

Sri Guru Ram Rai Post Graduate

College, Dehradun, 248 001,

Uttaranchal, India

\section{G. Krishna Kishore}

International Crops Research Institute for the Semi-Arid Tropics,

Patancheru 502324

Andhra Pradesh, India

\section{Chickpea in Nepal}

Chickpea (Cicer arietinum L.) is a leading pulse crop in Nepal. It is the second most important crop after lentil (Lens culinaris Medik.) among winter legumes grown in the Terai and inner Terai, the primary agricultural area of Nepal (Fig. 1). Chickpea is the principal source of dietary protein for an estimated 1.8 million Nepalese (12). Chickpea seed contains 12 to $30 \%$ protein and is rich in essential amino acids, carbohydrates, minerals, and vitamins $\mathrm{A}$ and $\mathrm{C}$ (23). The crop also fixes nitrogen in soil (40 kg N/ha) and reduces fertilizer costs in subsequent cereal crops such as rice and maize. However, the area under chickpea production in Nepal dropped from 54,000 ha in 1981-82 to only 19,000 ha in $1997-98$. The descending trajectory of chickpea was mainly due to its susceptibility to Botrytis gray mold (BGM). A BGM epidemic in 1997-98 completely destroyed the chickpea crop and virtually eliminated chickpea production from the country. BGM not only devastated the crop, but also caused serious shortages of seed for the following season.

Corresponding author: S. Pande E-mail: s.pande@cgiar.org

DOI: 10.1094/PD-89-1252

(C) 2005 The American Phytopathological Society
Other chickpea problems, such as Fusarium wilt, caused by Fusarium oxysporum Schlechtend.:Fr. f. sp. ciceris (Padwick) Matuo \& K. Sato, also are of considerable importance in chickpea production in $\mathrm{Ne}$ pal. Other fungal diseases, such as Ascochyta blight caused by Ascochyta rabiei (Passerini) Labrousse, Sclerotinia stem rot caused by Sclerotinia sclerotiorum (Lib.) de Bary, dry root rot caused by Rhizoctonia bataticola (Taubenhaus) E.J. Butler, wet root rot caused by Rhizoctonia solani Kühn, and damping-off caused by Pythium spp., are important production constraints in chickpea growing areas elsewhere, but are of minor significance in Nepal.

Chickpea was the integral part of the rice-based and maize-based production systems in Nepal. In these cereal-based production systems, rice and maize were grown in the rainy season and chickpea was the main post-rainy-season crop. Because of its drought tolerance, deep root system, and capacity to successfully utilize residual moisture, it was the preferred second crop of the cereal-based production system. In the past decade, particularly from the mid-1990s, chickpea was largely replaced by less remunerative crops such as lentil, pea (Pisum sativum L.), rape (Brassica napus L.), and mustard (Brassica juncea (L.) Czern.) (16), or the fields were left unsown, thus reducing farmer income. More than $75 \%$ of the rice fallows had adequate moisture for chickpea pro- duction, but were left unsown. Chickpea is a low-input crop with high water use efficiency (12 kg grain ha ${ }^{-1} \mathrm{~mm}^{-1}$ water), and its cultivation in the rice fallow lands has a direct bearing on the overall economic and financial well-being and nutritional status of subsistence farmers in Nepal.

\section{The Disease}

Botrytis gray mold disease of chickpea, caused by Botrytis cinerea Pers.:Fr., is the main production constraint in several of the chickpea growing areas of the world, where cool and humid weather persists in the crop season. The pathogen infects all aerial plant parts (Fig. 2), with growing tips and flowers being the most vulnerable $(5,15)$. Drooping of the infected tender terminal branches is a common field symptom (6). Often the symptoms appear first as a water-soaked lesion on the stem near ground level, which leads to breaking-off of the branches at the lesion point, and the affected leaves and flowers turn into a rotting mass $(1,15)$. The fungus can form gray to brown lesions with clear sporulation on leaflets, branches, and pods $(5,6)$. Lesions on pods are water-soaked and irregular, sometimes with black sclerotial bodies scattered in the infected areas. Pod lesions lead to the formation of shrunken, discolored seeds (Fig. 2D and E).

B. cinerea survives on seed, and also in infested soil and plant debris, where it survives for long periods. Due to its wide 


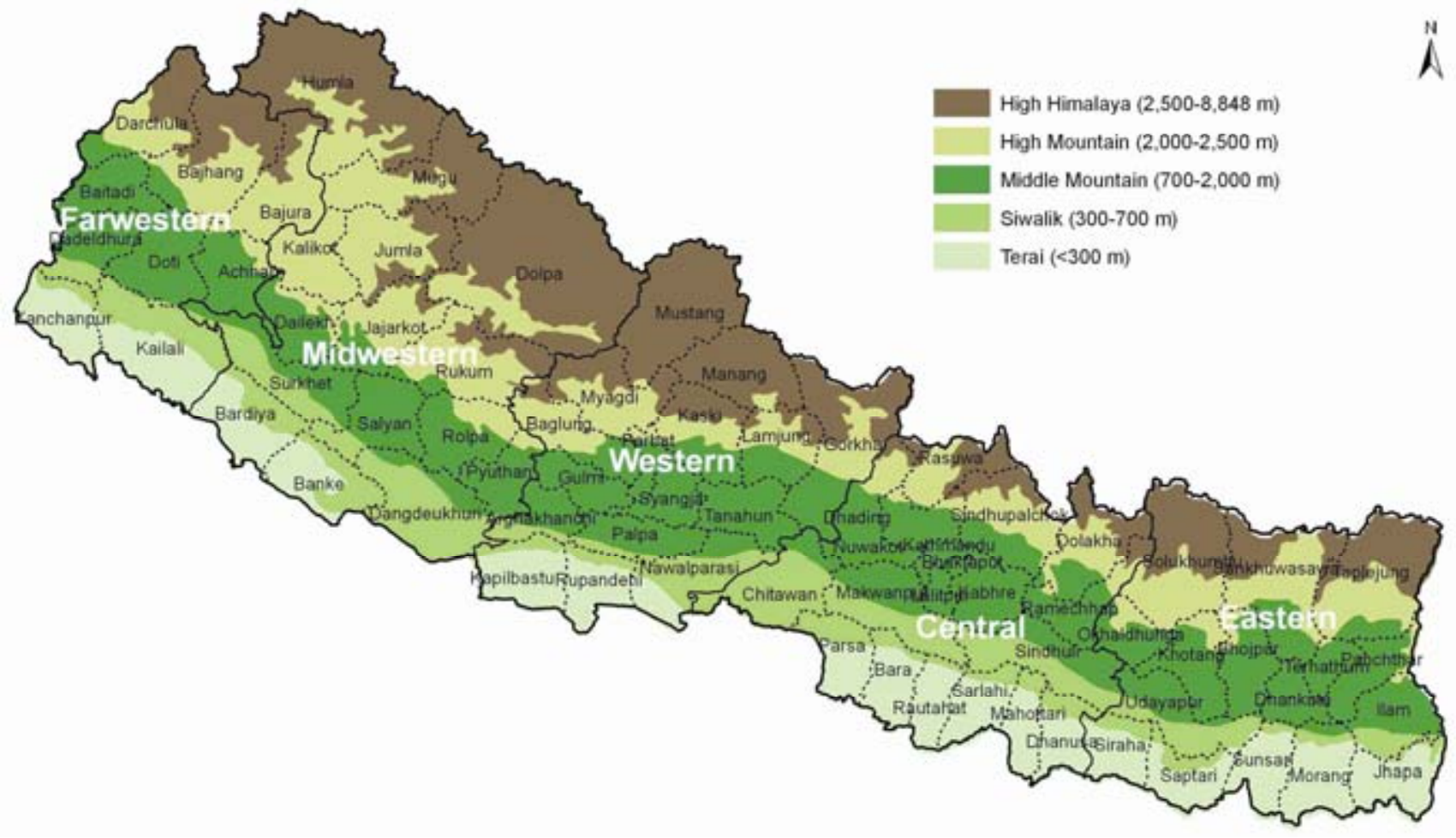

Fig. 1. Physiographic regions of Nepal (Source: Topographic Survey Branch, Department of Survey, His Majesty's Government, Nepal, 1983).
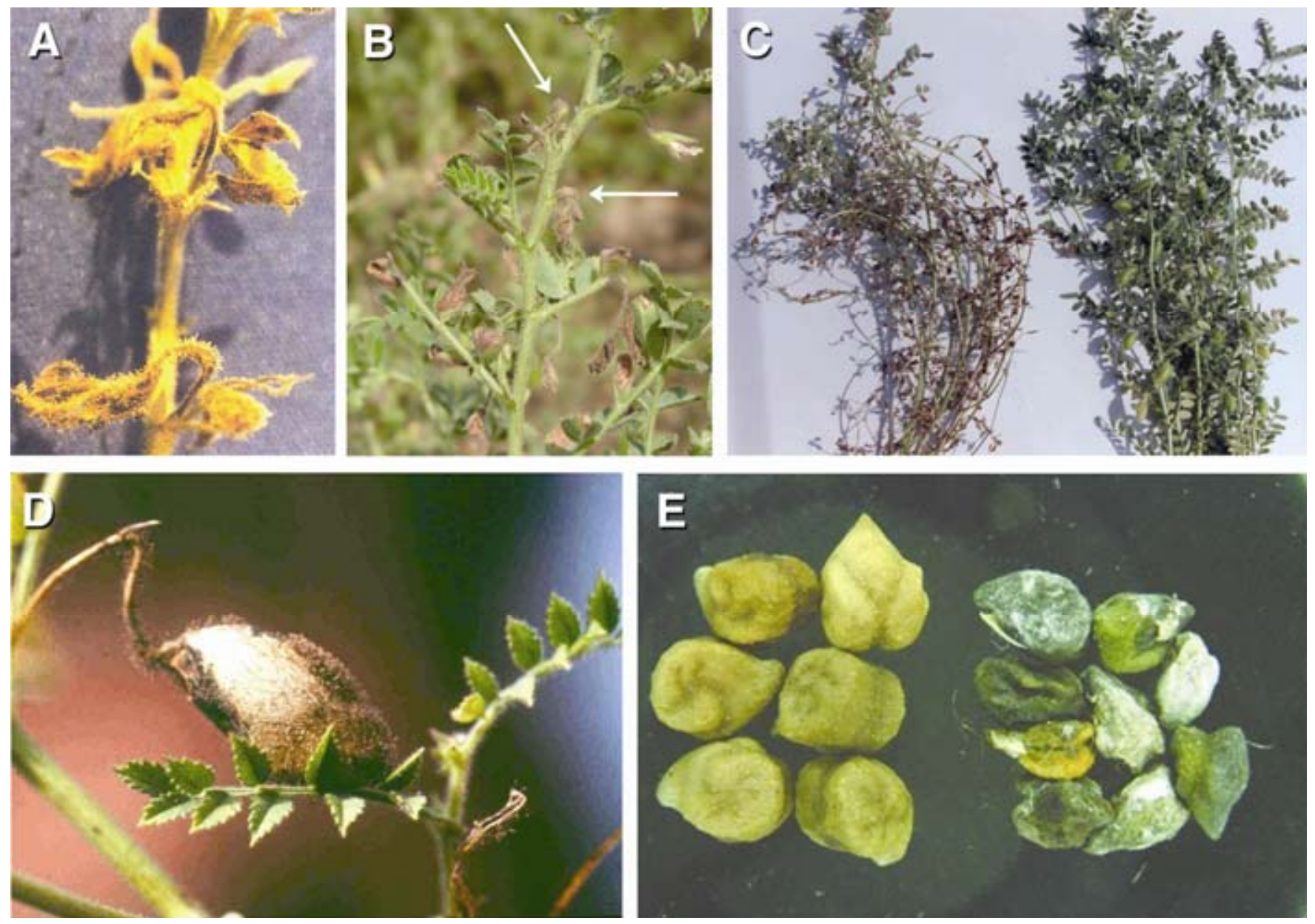

Fig. 2. Symptoms of Botrytis gray mold infection in chickpea: A, infected flower buds; B, infected twigs; C, infected leaves and branches; D, infected pods; and E, infected seed. 
host range, the role of alternative hosts is likely to play an important part in survival of $B$. cinerea from one chickpea crop to the next $(5,8,15)$. Relative humidity, leaf wetness, and temperature are the most important factors that facilitate rapid development of $\operatorname{BGM}(2,15,22)$. When relative humidity is $95 \%$ or above and temperatures are approximately $25^{\circ} \mathrm{C}$ in a dense canopy, the disease can spread rapidly and assume epidemic proportions within a short period, with the disease cycle completed in 7 days (5). BGM is one of the biological constraints for chickpea production in Nepal, and a severe BGM epidemic devastated the chickpea crop in 1997-98. The disease not only damaged the crop but also caused serious shortage of seeds for the following season.

\section{International Cooperation for Integrated Management of BGM}

In 1985, the Nepal Agricultural Research Council (NARC) established the National Grain Legume Research Program (NGLRP) in Chitwan. The main mandate of NGLRP is to identify and develop improved high yielding varieties of chickpea and other grain legumes in Nepal in collaboration with ICRISAT (16). Although several local and exotic chickpea germ plasm were evaluated for resistance to $\mathrm{BGM}$ in different agroecological regions of Nepal, an adequate level of resistance to BGM was not found in our preliminary studies. Further, in the absence of an effective technology transfer process and because of ineffective seed distribution, BGM tolerant varieties remained unavailable to farmers. Concurrently, investigations on cultural and chemical methods of BGM control were initiated $(3,20)$.

Since high levels of BGM resistance were not available in existing chickpea germ plasm and distribution of improvedtolerant genotypes was poor, BGM management in Nepal was forced to rely on fungicides. Chemical control of BGM

Identification of individual components

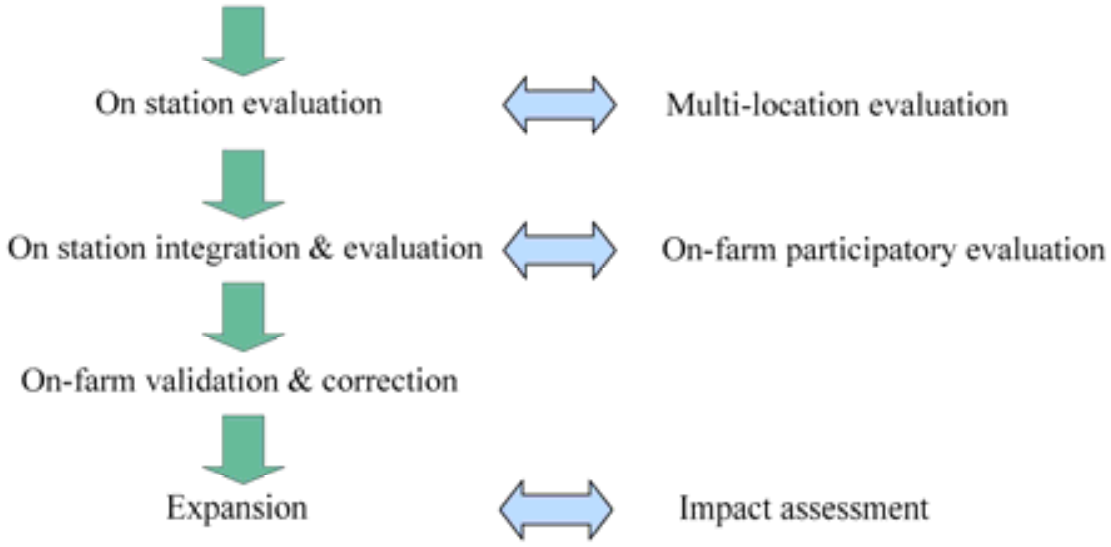

Fig. 3. Thematic structure for development of integrated crop management (ICM) technology. could be expensive for resource-poor farmers (15). The need for integrated management of BGM through a combination of available host plant resistance in highyielding chickpea cultivars, improved agronomic practices, and targeted spraying with effective fungicides was evident. The collaboration of three research institutions (ICRISAT, NARC, and Natural Resources Institute [NRI]) was undertaken to help Nepalese chickpea growers improve their management of BGM through farmer participatory approach. The goal of this collaboration was to assist poor marginal farmers in the inner Terai and Terai regions of Nepal with the following specific objectives:

(a) Develop and validate integrated management of BGM,

(b) Identify other major biotic and abiotic constraints to chickpea production and integrate their management options with that of BGM,

(c) Scale up chickpea production in partnership with farmers.

\section{Farmer Participatory Rural Appraisal}

To identify the constraints and opportunities in chickpea production, Participatory Rural Appraisals (PRAs) were conducted with 500 farmers from 16 districts distributed across the Terai (12). The number of districts chosen from each region was based on the extent of chickpea production in that region. Villages were selected randomly from these districts, and chickpea each village. The number of chickpea producers selected in each region was based on the proportion of land sown with chickpea in that region: eastern Terai (3 districts), 55; central Terai (6 districts), 75; western Terai (3 districts), 95; midwestern Terai (2 districts), 235; and far western Terai (2 districts), 40. Data were collected in a pretested questionnaire and given to farmers in their local language. Farmers producers were selected randomly from were asked questions on general information, land use pattern, enterprise choices, economics of chickpea and other competitive crops, benefits of chickpea production, and constraints. Information was also sought on marketing and consumption of chickpea.

The PRA studies indicated that BGM caused an average pod yield loss of more than $70 \%$. Pod borer insect, Helicoverpa armigera (Hubn.), and Fusarium wilt also were identified as causes of substantial crop damage. Additionally, poor soil fertility and boron deficiency were identified as major abiotic constraints. Poor nodulation was observed in many regions. Difficulties in obtaining good seed were another major constraint that had a severe impact on successful chickpea production. With no chemical and biological methods adopted by the farmers to preserve seed, more than a third of chickpea seed often is damaged in storage. Farmers reported low germination due to poor quality seed. Thus, management of BGM alone may not be effective in promotion of chickpea in Nepal, since the crop is susceptible to a range of other biotic and abiotic constraints. In this context, we strove for simultaneous management of these biotic and abiotic constraints as a part of the package of improved practices of chickpea production. The efforts of integrated disease management of BGM were expanded to integrated crop management (ICM) by adding other pest and nutrient (boron) management strategies to make chickpea production more reliable (12).

\section{Identification of Components of ICM}

The development and validation of ICM technology was based on a thematic structure, starting with identification of individual components of technology, followed by integration of components and validation of integrated components both on-station and on-farm. Transfer of the technology and its impact was assessed (Fig. 3). Since $\mathrm{BGM}$ is a major production constraint, deployment of moderate levels of host plant resistance and judicious application of fungicides for BGM management are important as basic components of ICM technology. We used several single factor technologies for disease, pest, and nutrient management as components of a multifactor-based ICM technology. Single factor technologies are available for management of pod borer by foliar application of insecticide (19) or the biological agent Helicoverpa nucleo polyhedrosis virus (HaNPV). Boron deficiency is alleviated by foliar application of boron as boric acid (21).

I. Host plant resistance for BGM. More than 5,000 accessions of chickpea germ plasm and breeding lines were evaluated for BGM resistance in the fields, in collaboration with Govind Ballabh Pant 
University of Agriculture and Technology (GBPUAT), Pantnagar, Uttaranchal State, India, and at the Regional Agricultural Research Station (RARS), Tarhara, Nepal. Disease resistance of selected chickpea lines was further confirmed in controlled environments at ICRISAT, Patancheru, Andhra Pradesh, India.

In field trials, accessions were sown in 4-m-long rows, with susceptible cultivar $\mathrm{H}$ 208 sown as a spreader row after every two test rows. At the initiation of flowering, both the test and infector-cum-indicator rows were sprayed with a conidial suspension $\left(2 \times 10^{5}\right.$ conidia/ml $)$ of $B$. cinerea. Sprinkler irrigation was provided the following morning for $15 \mathrm{~min}$ at 1 - to 2 -h intervals from 0900 to $1900 \mathrm{~h}$ if the weather was dry. The plots were reinoculated with $B$. cinerea 10 days after the initial inoculation. Disease severity on a 1 to 9 rating scale $(1=$ no infection; $9=81$ to $100 \%$ defoliation of leaves, flower and pod infection, and complete drying of stem) was recorded twice, once when the BGM rating in the indicator row was 9.0,

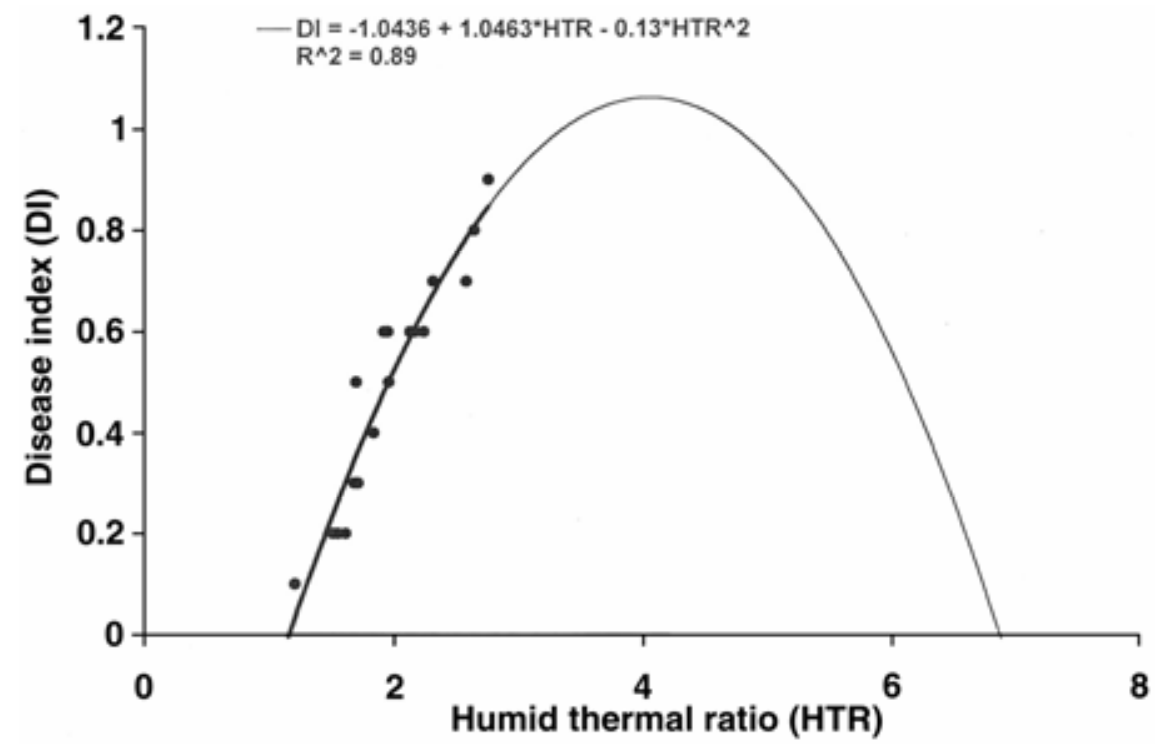

Fig. 4. Predictive model for Botrytis gray mold (BGM) infection in chickpea.
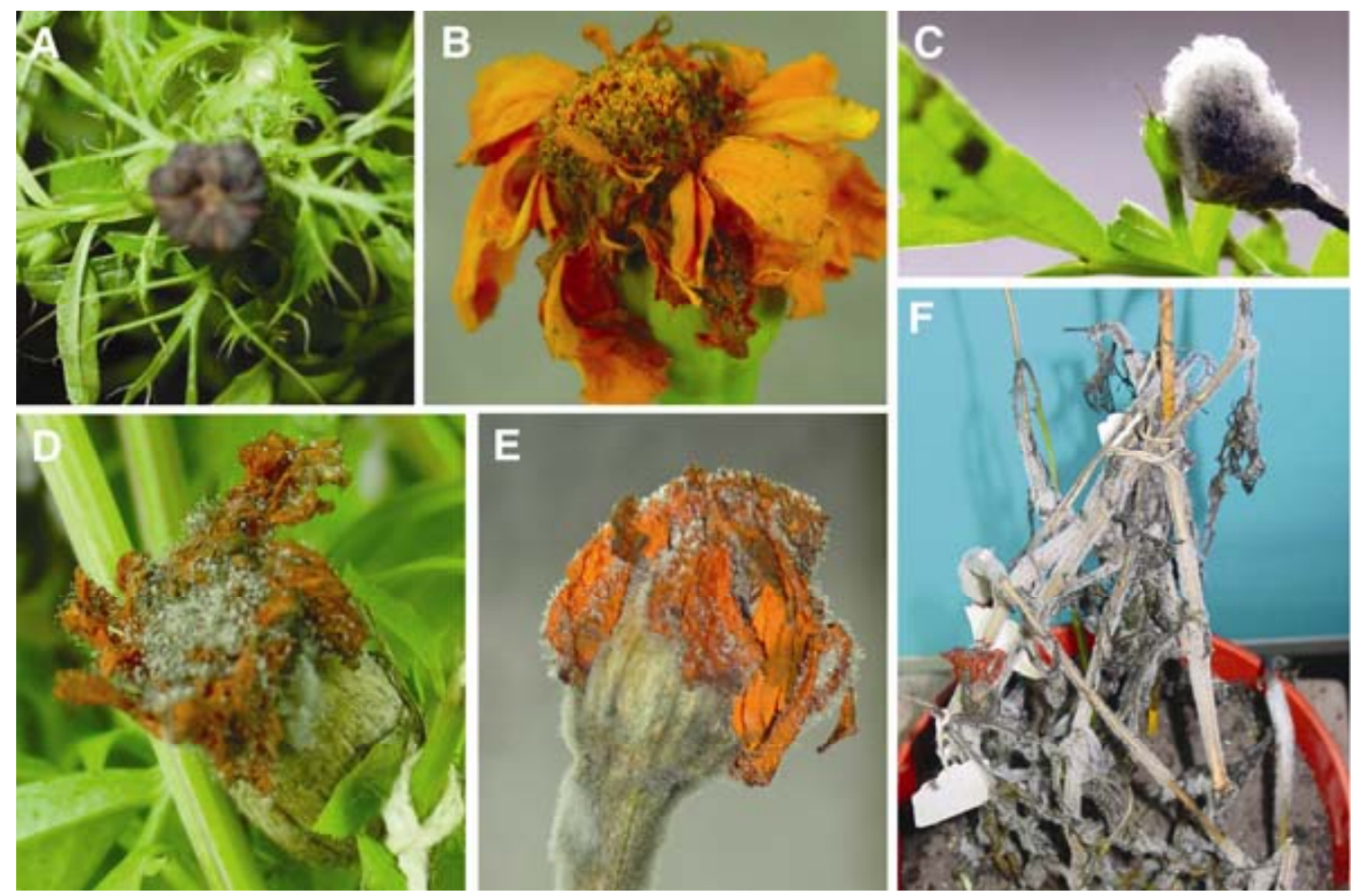

Fig. 5. Progressive symptoms of Botrytis cinerea infection on the flowers of Tagetus erecta: A, rotting of young buds; B, initial lesions on petals; C, flower buds completely covered with sporulation and lesion development on leaves; D, evident sporulation on flower; E, flower completely covered with sporulation; and F, sporulation on all aerial plant parts. 
(9). The fungus also is airborne, and its secondary spread is mainly through wind transmission.

Seed treatment with various fungicides reduces seedborne infection of BGM. Also, foliar sprays at regular intervals from the first appearance of the disease can protect the crop (4). Sometimes multiple sprays are recommended, although generally one spray at flowering followed by another spray 10 days later on a moderately resistant chickpea cultivar provide good protection (15). In our preliminary field experiments, we observed that seed treatment with carbendazim and thiram combined with two foliar sprays of carbendazim at 14-day intervals starting from flowering were the most effective chemical treatments against BGM. Carbendazim was selected because of its easy availability to farmers compared with other fungicides.

III. Farmer-friendly forecasting model to guide fungicide application. Weather variables and BGM severity data over an 18-year period were used to develop a disease prediction model. Maximum temperature and afternoon $\mathrm{RH}$ were identified as important components of the model. A function of these two variables, referred to as humid thermal ratio (HTR), was fitted to a quadratic function and forms the basis for a predictive scheme to schedule fungicide sprays for managing BGM (Fig. 4). This predictive model, based on complex mathematical calculations, is difficult for farmers to follow. We evaluated Tagetus erecta L. (marigold), another host of $B$. cinerea that is commonly grown in the yards of chickpea farmers, as an indicator plant to develop a "farmer friendly" forecasting model (Fig. 5). BGM infection of $T$. erecta flowers has similar symptoms to those in chickpea. Additionally, the clear visibility of BGM infection on large-sized flowers of marigold facilitated farmers to detect the disease early and initiate timely prophylactic protection of the chickpea crop. In contrast, BGM infection on the small chickpea flowers often remained unrecognized by farmers until the foliage was already damaged and foliar sprays could not provide maximum protection.

IV. Effect of row spacing on BGM. Reduced plant density may reduce BGM severity because of more aeration in the crop canopy, which results in reduced periods of leaf wetness below the requirement for disease development. In experiments conducted by ICRISAT and NARC (Nepalgunj, Rampur, Nawalpur, and Tarhara), it was observed that BGM incidence was lower at wider row spacing than at closer spacing in both fungicide-sprayed and nonsprayed plots. Among the different row spacings tested, $60-\mathrm{cm}$ spacing with fungicide application had the least disease severity and maximum grain yields (14).

V. Seed treatment with Rhizobium for better nodulation. Soil application of peat formulation of Rhizobium (210 g/ha) mixed in fine soil at the time of planting was tested to determine if it could overcome the poor nodulation of chickpea. Inoculation substantially increased nodule formation in the field; the extent of nodulation, scored on a 1 to 5 rating scale (18), was 3.4 in Rhizobium-treated plots in contrast to 1.8 in untreated plots.

VI. Integration of components of ICM. The single-factor options for management of BGM, pod borer, poor nodulation, and boron deficiency were integrated and evaluated as an ICM package for chickpea (Fig. 6). This ICM technology is a combination of integrated disease management (IDM), integrated pest (insect) management (IPM), and integrated nutrient management (INM) technologies. Fungicide sprays for BGM management were decided based on the incidence of BGM on the flowers of $T$.

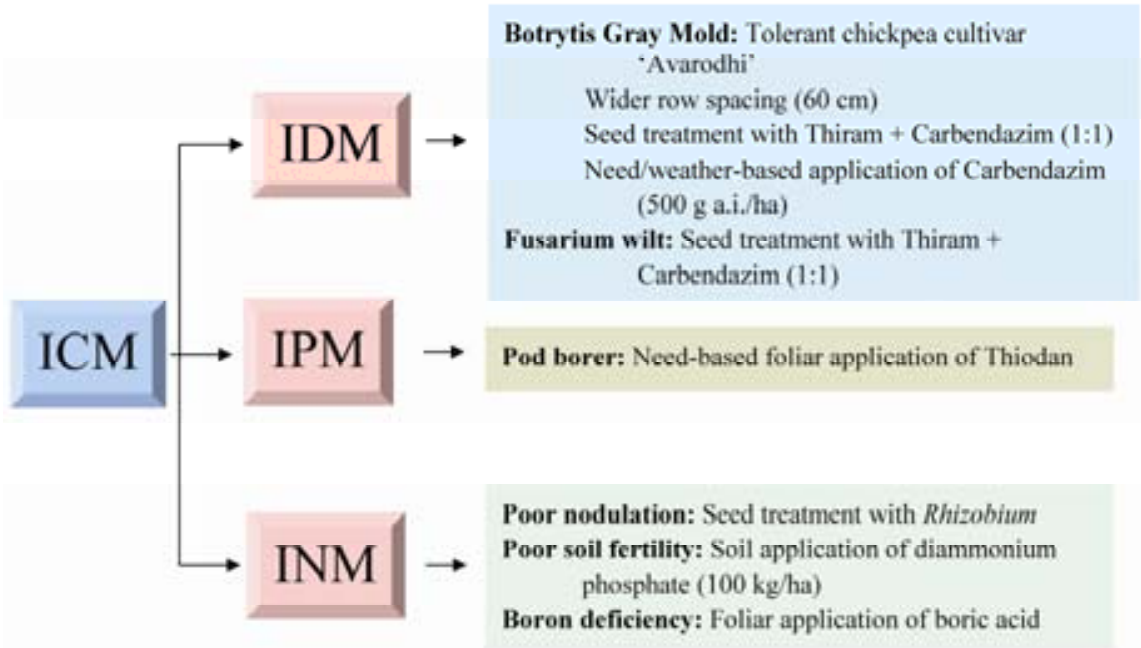

Fig. 6. Components of ICM technology of chickpea. ICM = integrated crop management; IDM = integrated disease management; IPM = integrated pest management; INM $=$ integrated nutrient management. erecta grown in or adjacent to the chickpea fields. In general, these spray schedules coincided with vegetative-flowering, pod formation, and pod development stages of the crop. To manage pod borer, insecticide was sprayed once during flowering and twice during pod-filling stages, depending on the larval populations (application threshold: one larva per meter of row).

\section{Validation of ICM}

Selection of sites. Eighteen villages from 11 districts in Nepal were selected for on-farm validation of the ICM technology (Fig. 7). Villages selected were representatives of these districts in topography, and were located relatively close to collaborators who were monitoring the trials. Submarginal, marginal, and small farm agriculture was a consistent feature of the selected villages. The key characteristics of the farm sites chosen for validation of ICM technology were as follows (17):

(d) Chickpea was grown in rice-based cropping systems, and the production constraints (biotic and abiotic) were prevalent with a high degree of uniformity.

(e) It was possible to group the participating farmers into units that had similar management practices and were cultivating chickpea as an integral part of the traditional rice-based cropping system.

(f) Areas chosen were where the numbers of small farmers or farmers' groups were greater than the number per replicate or block.

Selection of farmers. In each selected village, a meeting was held with farmers and rapid appraisals were conducted. The objectives, methodology, and advantages of ICM technology were explained, and farmers' perception and preference of chickpea production were discussed. Farmers' participation was solicited on a voluntary basis, and preference was given to women farmers, as they were found to be more responsive to educational efforts and managed the farming in the absence of men, who after rice harvest usually migrate to cities or to neighboring countries in search of work. During the 1998-99 post-rainy season, 110 farmers participated, and in the 1999-2000 post-rainy season, 503 farmers, including 110 farmers of the 1998-99 season, participated. In the 2000-2001 post-rainy season, a total of 883 farmers were selected for the study. Across the regions, farm sizes varied from $0.83 \mathrm{ha} /$ farmer in the central Terai to 2.58 ha/farmer in the far western Terai. Participating farmers broadly possessed the following characteristics, as suggested by Ray et al. (17):

(g) willing to accept innovations and concerned about chickpea production constraints, 
(h) grow chickpea using normal agronomic practices and ready to provide some labor as under normal research situations,

(i) willing to carry out ICM operations as prescribed by the research staff,

(j) agreeable to co-operating without any financial incentives other than free seed and crop protection material,

(k) willing to provide at least $1 \times 1 \mathrm{~m}$ plot or multiple of it for assessing seed yield.

Treatments, genotypes, and design of the experiment. At all locations, the trial consisted of two treatments: ICM and nonICM. The ICM package consisted of improved cv. Avarodhi and all other components as mentioned above. The non-ICM package consisted of a local cultivar with none of the inputs of ICM. Seeds of both cultivars (Avarodhi and local cultivar) sufficient to plant one Katha (338 $\mathrm{m}^{2}$ area) were provided to all of the participating farmers. The crop was sown as per local practices after rice (one light tillage operation before broadcasting of seed, and one tillage operation to cover the seed). Sowings were done only in the presence of a NARC and/or ICRISAT scientist.

Farmers' training. Orientation schools were conducted three times during the crop season in each village to increase awareness among the participating farmers on diagnosis of biotic and abiotic constraints and their timely management. The first school was held 30 to 40 days after sowing, and farmers were encouraged to share their perception of chickpea production constraints, and management options were explained to them (Figs. 8 and 9). In the second and third orientation schools, held at the flowering and pod formation stages, diagnosis, epidemiology, and management of BGM and pod borer were emphasized. Information bulletins and brochures with pictorial representation of chickpea production constraints and their management were prepared in Nepalese colloquial language and distributed to the participating farmers (Fig. 10).

Disease and pest monitoring. In each village, an educated, young, enthusiastic farmer with good social relations to all the villagers was identified as a scout for regular monitoring of BGM and pod borer incidence. These village scouts were given special training (classroom and on-farm) on the identification of diseases and insect pests, and disease epidemiology and management, including safe application of fungicides and insecticides. The village scouts routinely monitored all the trials in that village and assisted the participating farmers in disease-pest diagnosis and timely application of fungicide and insecticide.

Disease, pest, and yield measurements. Ten each of ICM and non-ICM trials were selected at random from each

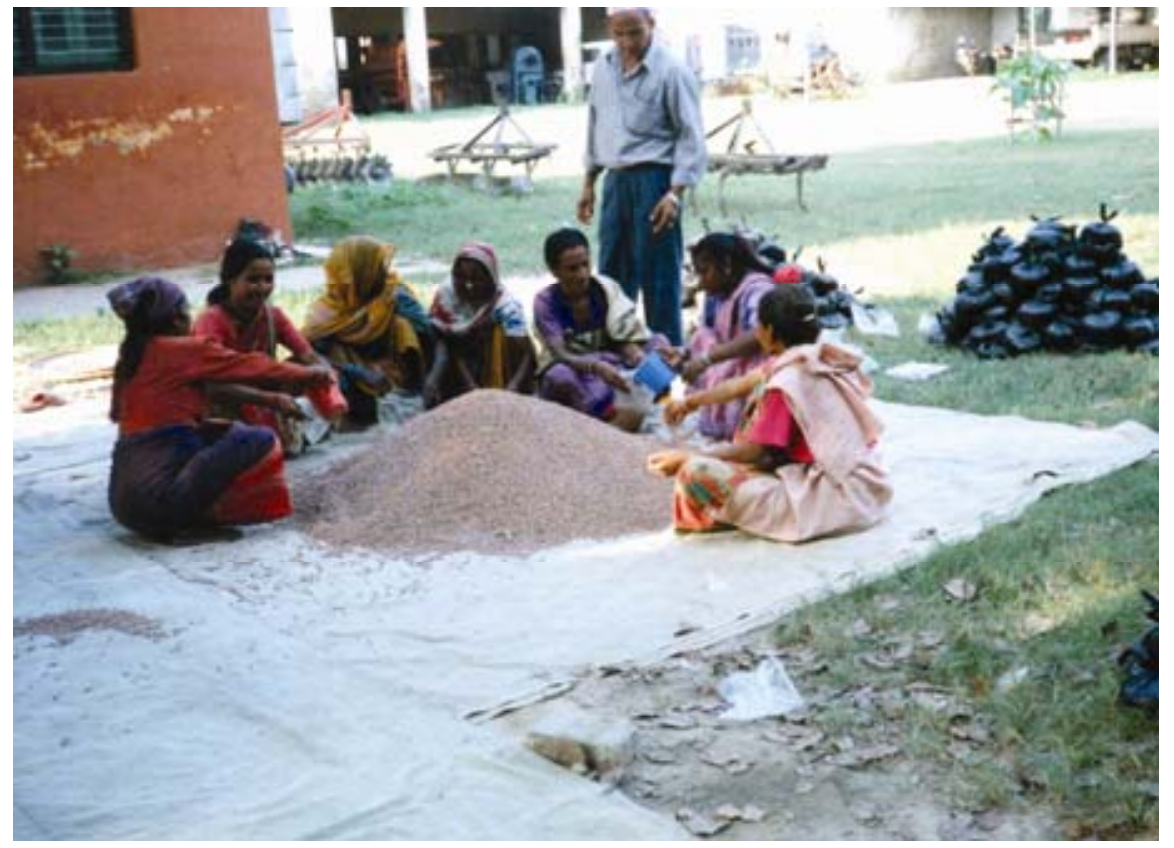

Fig. 8. Training of women farmers in seed treatment.

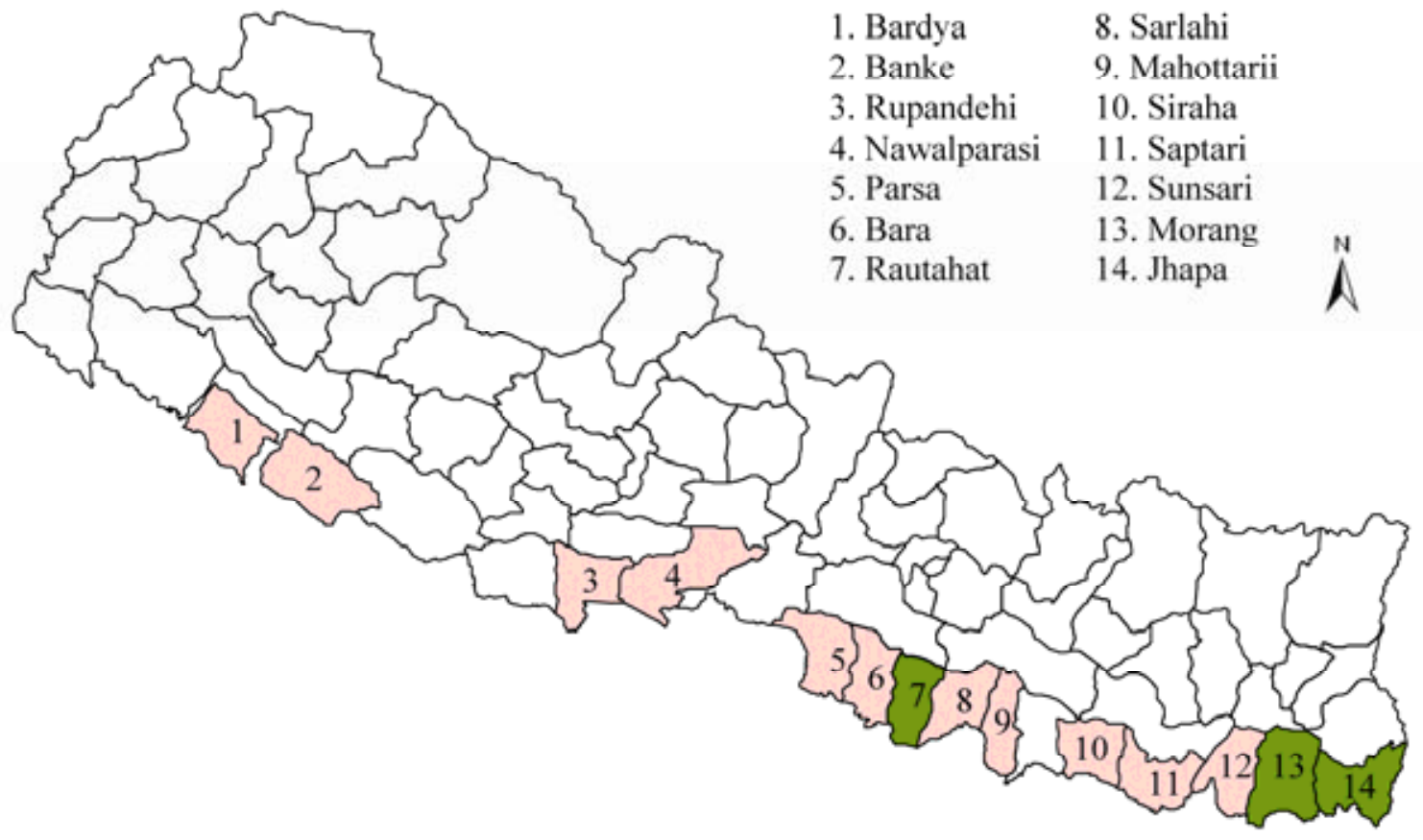

Fig. 7. Location of districts in Nepal, where integrated crop management technology of chickpea was introduced (pink) and further expanded (green). 
village for detailed observations. In all of the trials, three quadrats of $1 \times 1 \mathrm{~m}$ were randomly selected and demarcated in each treatment 30 days after sowing, and detailed observations were recorded in these plots as follows: (a) plant stand, (b) Fusarium wilt and root rot incidence, (c) BGM severity assessed on a 1 to 9 rating scale, (d) pod borer severity assessed by counting the number of larvae per plant at vegetative, flowering, pod filling, and near maturity, (e) percent pod borer damage, by counting the number of healthy and borerdamaged pods on five randomly selected

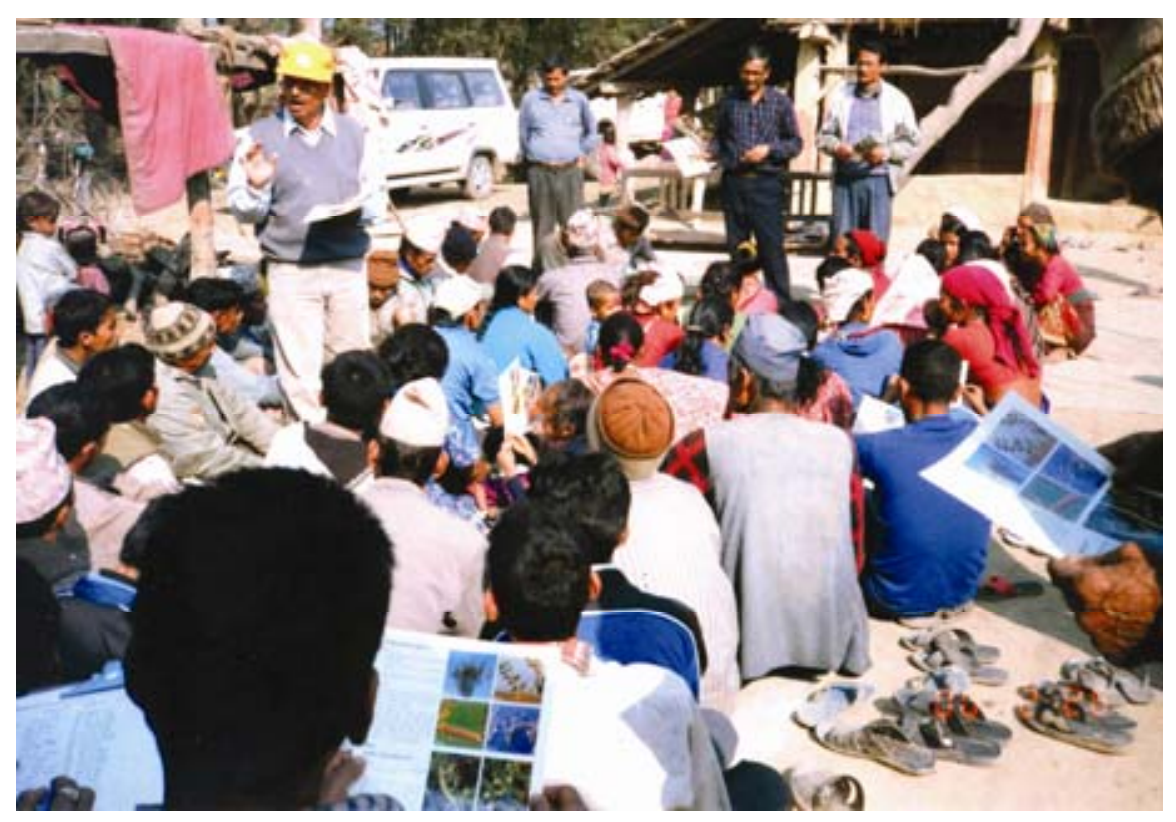

Fig. 9. Village level farmer orientation schools for integrated crop management promotion.

plants at harvest, (f) nodulation score on 1 to 5 visual rating scale, $(\mathrm{g})$ total number of plants at harvest, (h) total pods per plant at harvest, based on 15 plants, and (i) grain yield in $\mathrm{t} / \mathrm{ha}$ (based on three quadrats).

\section{Successful Chickpea Production Through ICM}

In on-farm ICM trials conducted during 1998 to 2001, ICM technology significantly and visibly reduced disease and pest incidence, and increased plant stand, nodulation, and grain yield (Fig. 11). The extent of these beneficial effects differed from location to location and year to year. The effects of ICM technology on chickpea production compared with non-ICM practice in three crop seasons, 1998-99, 19992000, and 2000-2001, are presented in Table 1.

\section{Economics of ICM}

The recommended ICM technology changed the economics of chickpea in Nepal because the ICM package was highly profitable and cost-effective. On the basis of information gathered from 200 participating farmers from midwestern Terai and central Terai, the cost of the ICM package was $13 \%$ higher than with nonICM production. However, net returns using ICM were US $\$ 316 /$ ha compared with only US $\$ 153 /$ ha for non-ICM, a gain of about $107 \%$. The cost of producing one

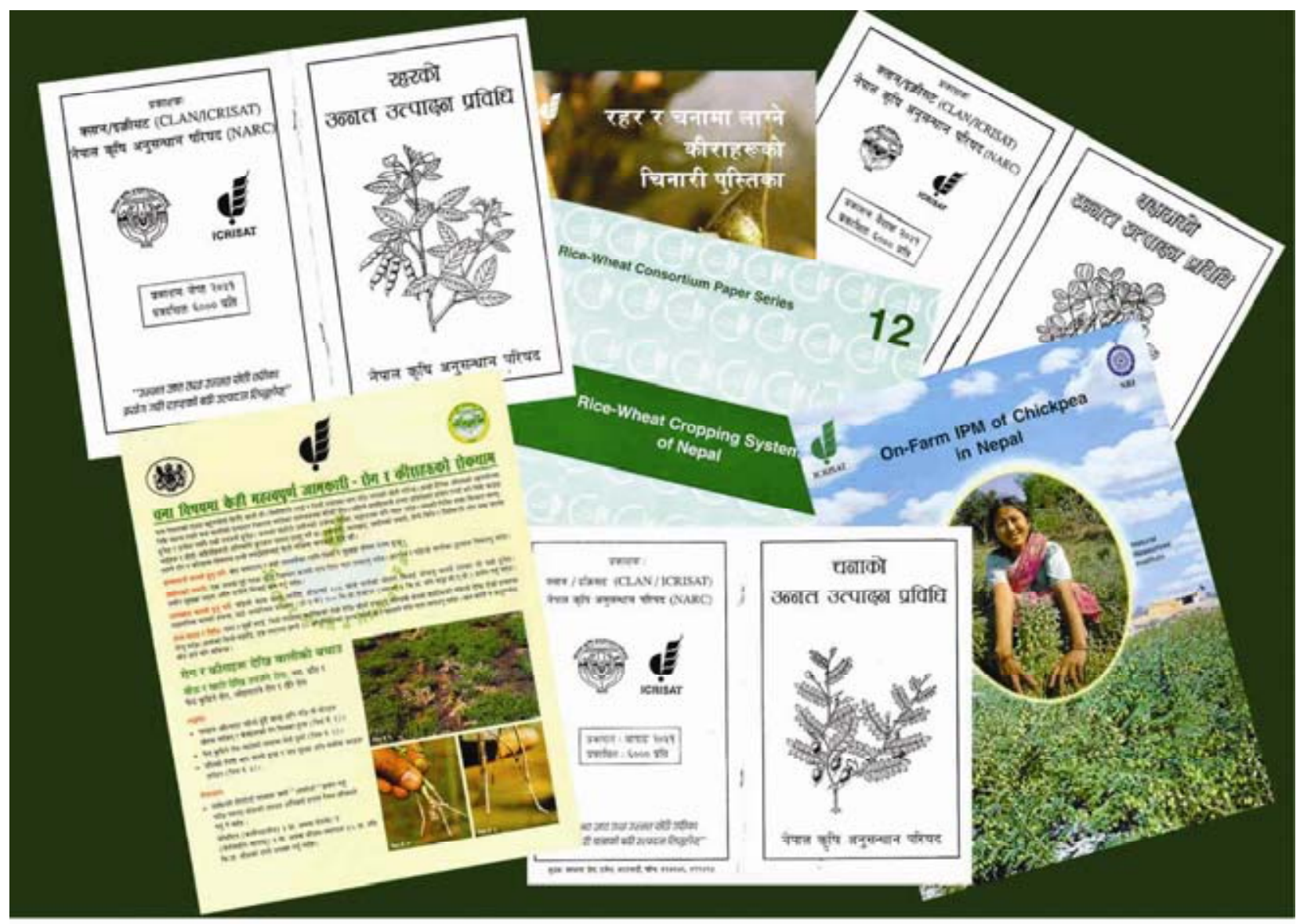

Fig. 10. Integrated crop management promotional material translated into colloquial languages of Nepali and Hindi. 
kg ICM chickpea was US\$0.16 compared with US\$0.29 with non-ICM practices, approximately $45 \%$ less (Table 2). The benefit-cost ratio of chickpea production using ICM was estimated to be 2.02 compared with 1.61 in non-ICM practice (13). For a sustainable and substantial impact of this resource-conserving crop, the benefits of ICM had to be promoted to farmers on a

\section{Adoption of ICM}

Following the successful demonstration of ICM technology in three consecutive crop seasons, additional demonstration trials (Fig. 12) were added. We observed a high adoption rate of ICM technology in the contact villages, and the technology much larger scale.

spread rapidly to nearby villages with subsequent implementation in 14 districts of Nepal (Fig. 7). Large-scale adoption of the ICM technology was due to its cost effectiveness.

Initiated in 1998, the ICRISAT-NARCNRI collaboration has achieved many of its objectives. The program began with 110 farmers, and in the following season there was a fivefold increase in the number of farmers who voluntarily adopted the ICM technology on 1 Katha $\left(338 \mathrm{~m}^{2}\right)$ to 10 Katha each. The good news kept spreading, and by 2000-2001, 1,100 farmers were sowing chickpea. The best news was that ICM technology was adopted by 7,000 farmers during the 2001-2002 season, and more than 20,000 farmers in 2004-2005

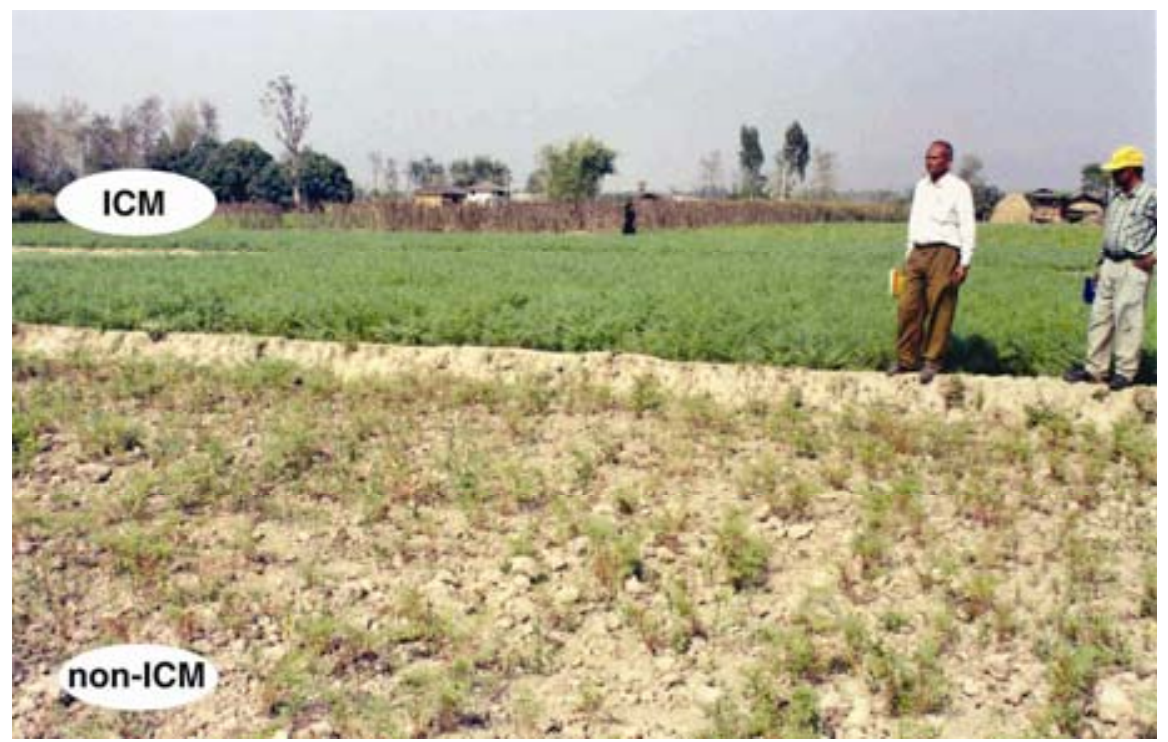

Fig. 11. Successful management of Botrytis gray mold through integrated crop management (ICM).
(Fig. 13) started growing chickpea, on a total of about 6,500 ha.

\section{Impact of ICM}

The impact of ICM technology on the livelihoods of resource-poor farmers in Nepal was estimated through structured surveys. The data were collected from 200 farmers in midwestern Terai and central Terai. In an exercise of participatory learning, the respondents were asked to fill in a questionnaire pertaining to livelihood impact of ICM technology. Although the impact of ICM chickpea production varied from village to village and farmer to farmer, chickpea ICM was a catalyst to improve the livelihoods of poor farmers. Its impact included an increase of: (a) family income by 80 to $100 \%$, (b) protein consumption of the farmer families by $40 \%$, (c) brick and mortar houses by $22 \%$, (d) labor use in agriculture and nonagricultural jobs by $20 \%$, (e) household expenditure by $45 \%$ and payback of debts, and (f) increase in livestock ownership by $30 \%$ (11).

Chickpea production also has economically benefited the farmers by additional wealth generation as follows: (a) seed transaction benefits by selling the excess seed of improved cultivar Avarodhi; average household seed transaction is about $127 \mathrm{~kg}$ of seed, which farmers sold to other farmers and also to nongovernment organizations (NGOs) at US $\$ 0.45 / \mathrm{kg}$; (b) sale of surplus products; (c) consumption of chickpea to combat malnutrition; (d) reduced fertilizer inputs in subsequent rice crop compared with rice-wheat rotation: rice-chickpea rotation reduced the requirements of urea to $24 \mathrm{~kg} / \mathrm{ha}$ from $71 \mathrm{~kg} / \mathrm{ha}$, diammonium phosphate (DAP) from 85 to $61 \mathrm{~kg} / \mathrm{ha}$, and compost from 7.6 to $5.2 \mathrm{t} / \mathrm{ha}$; and (e) increase in yield of rice in the next

Table 1. Effect of integrated crop management (ICM) practices on the growth of chickpea, and disease and pest incidence in on-farm trials from 1998 to $2001^{\text {a }}$

\begin{tabular}{|c|c|c|c|c|c|c|}
\hline \multirow[b]{2}{*}{ Observation $^{b}$} & \multicolumn{2}{|c|}{ 1998-99 } & \multicolumn{2}{|c|}{ 1999-2000 } & \multicolumn{2}{|c|}{ 2000-2001 } \\
\hline & ICM & non-ICM & ICM & non-ICM & ICM & non-ICM \\
\hline Plant stand ${ }^{c}$ & 2.5 & 3.1 & 2.6 & 3.1 & 1.7 & 2.8 \\
\hline Botrytis gray mold severity & 2.9 & 8.3 & 2.1 & 7.1 & 3.0 & 8.5 \\
\hline Pod borer infestation ${ }^{\mathrm{f}}$ & 1.5 & 5.5 & 1.2 & 5.8 & 0.8 & 5.5 \\
\hline Pod borer damageg & 2.9 & 40.0 & 3.7 & 45.4 & 5.4 & 54.3 \\
\hline Nodulation $^{\mathrm{h}}$ & 3.4 & 2.5 & 3.7 & 2.0 & 3.4 & 1.8 \\
\hline Total plants at harvest $\left(/ \mathrm{m}^{2}\right)$ & 37.2 & 29.0 & 24.0 & 20.0 & 23.0 & 18.0 \\
\hline Number of pods per plant & 62.0 & 35.0 & 82.0 & 40.0 & 73.0 & 38.0 \\
\hline Grain yield (t/ha) & 2.0 & 1.1 & 2.4 & 1.1 & 2.1 & 0.90 \\
\hline
\end{tabular}

${ }^{a}$ Mean values were based on 180 ICM and non-ICM trials in 18 villages of 11 districts. All mean values in ICM treatment differ significantly $(P<$ $0.01)$ from non-ICM in all 3 years.

b Plant stand was recorded 30 days after sowing; all other observation presented were recorded at harvest.

c Plant stand was recorded on a 1 to 9 rating scale, where $1=>90 \%$ emergence and $9=<10 \%$ emergence.

${ }^{\mathrm{d}}$ Severity of Fusarium wilt and root rots was recorded on a 1 to 9 rating scale, where $1=$ no plant mortality and $9=80$ to $100 \%$ plants killed by Fusarium wilt and/or root rots.

e Botrytis gray mold severity was recorded on a 1 to 9 rating scale, where $1=$ no infection and $9=81$ to $100 \%$ defoliation of leaves, flower and pod infection, and complete drying of stem.

${ }^{f}$ Pod borer infestation was measured by counting number of larvae per plant.

g Pod borer damage was measured as percentage of damaged pods compared with total pods on five randomly selected plants.

h Nodulation was recorded at harvest on a 1 to 5 rating scale. 
season. These economic benefits ranged up to US\$5,000 per village (Table 3 ). In Lelbandi village, there was a chickpea revolution among the farmers and some earned profits up to US\$1,000 in one season, a large amount in the rural areas of Nepal.

\section{Establishment \\ of Village Level Seed Systems}

Along with adoption of ICM practices, chickpea farmers have adopted the practice of seed storage for the next season. Some farmers preserved seed to sell to other farmers. The chickpea seed market-business is thriving in villages. Participating farmers store about $15 \mathrm{~kg}$ of seed, and indirect contact farmers stored $25 \mathrm{~kg}$ of seed on average, for use in the next crop season. The farmer-to-farmer sale of chickpea seed is quite popular and remunerative in many of the villages.

A few enthusiastic young farmers and
Table 2. Economics of chickpea production with and without ICM

\begin{tabular}{lccc}
\hline Particulars (/ha) & Non-ICM (US\$) & ICM (US\$) & $\begin{array}{c}\text { \% Change of ICM } \\
\text { over non-ICM }\end{array}$ \\
\hline Material cost & 70.9 & 72.2 & 1.88 \\
Operational cost & 175.7 & 199.1 & 13.4 \\
Interest on working capital & 2.8 & 2.9 & 1.2 \\
Total cost & 249.4 & 274.2 & 10.0 \\
Gross income & 402.0 & 590.7 & 47.0 \\
Net income & 152.6 & 316.4 & 107.0 \\
Unit cost of production $(/ \mathrm{kg})$ & 0.29 & 0.16 & -44.8 \\
\hline
\end{tabular}

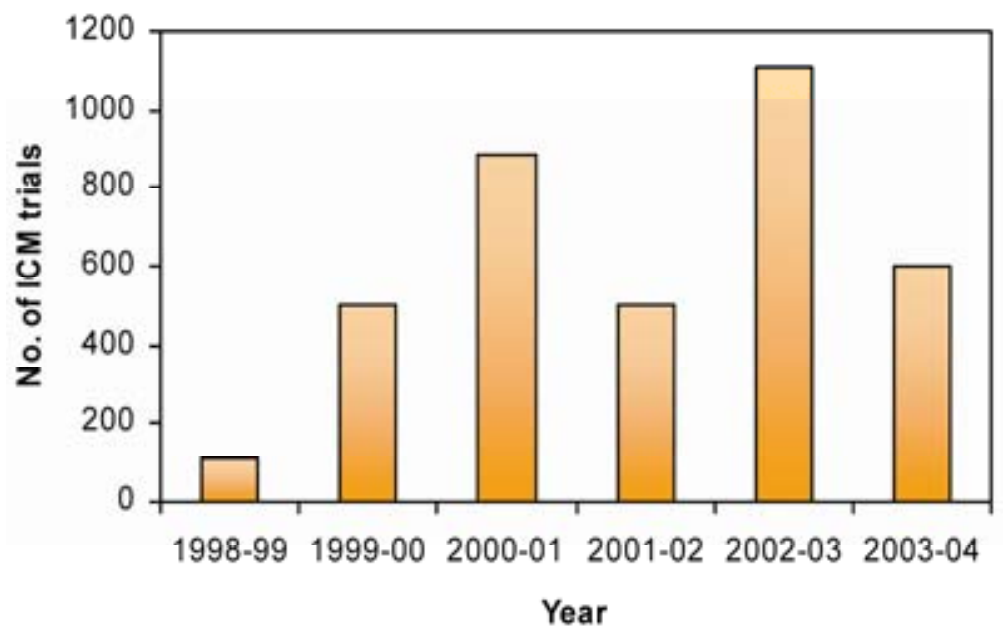

Fig. 12. On-farm participatory integrated crop management (ICM) trials conducted for Botrytis gray mold management in Nepal.

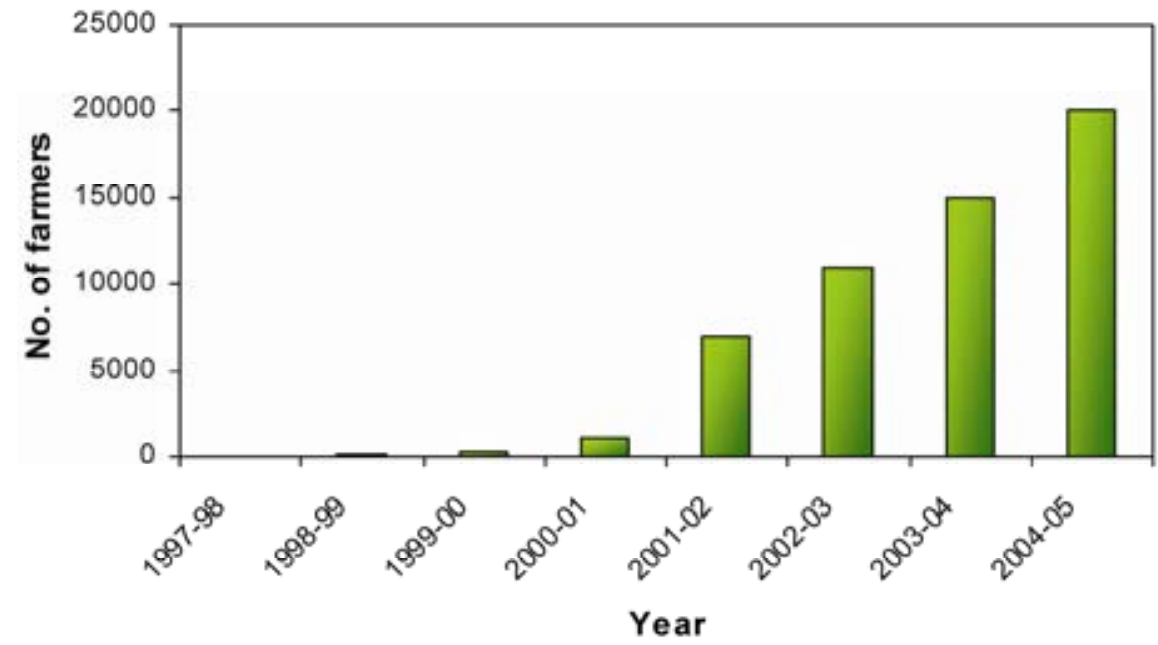

Fig. 13. Increase in number of farmers implementing integrated crop management in chickpeas in Nepal, 1997 to 2005. farmer groups showed interest in largescale seed production of the improved cultivar Avarodhi due to its low disease susceptibility and high yield. In a villagelevel seed system, participating farmers were trained especially to minimize the damage during seed storage. The farmers' seed production association in the village Pithuwa and some enthusiastic individual farmers in Lalbandi initiated production of good quality seed for selling to farm communities. About five tons of seeds of the improved varieties were harvested in 2003-2004 and sold as seed in the subsequent crop season. The village Bardibas in Mohathari district was identified as a chickpea seed village in 2002-2003. In the subsequent season, seed sales spread to different villages within a radius of 10 to $45 \mathrm{~km}$.

\section{Outlook for the Future}

The ICM technology developed at ICRISAT was successful in rehabilitation of chickpea in Nepal and stands as a model for chickpea promotion in India and Bangladesh. Introduction of similar ICM technology in eastern and western regions of Nepal is desirable since these regions have very large rice fallow lands. Some innovative approaches can be introduced to involve farmers in deciding research needs and their ultimate dissemination. In this context, the ongoing program is completely dependent on farmer participation and is expected to set a model for largescale technology transfer. Thus, farmers' training and involvement of nongovernment organizations, in addition to disease, pest, and nutrient management, are essential for sustainability of chickpea in Nepal. Community participation in seed storage and production of nucleo polyhedrosis virus (for pod borer management) need to be encouraged in the chickpea growing areas of Nepal.

To further improve the economics of chickpea production, a source of host-plant resistance needs to be developed. High

Table 3. Impact ${ }^{\mathrm{a}}$ of chickpea on wealth generation in the village D-Gaon, district Banke

\begin{tabular}{lr}
\hline Economic benefit & \multicolumn{1}{c}{$\begin{array}{c}\text { Value } \\
\text { US\$ }\end{array}$} \\
\hline Seed transaction benefits & $1,143.0$ \\
Sale of surplus product & $2,250.0$ \\
Consumption of chickpea & 500.0 \\
Reduced burden of & 223.7 \\
fertilizers & 600.0 \\
Increase in rice yield & $4,716.3$ \\
Total & \\
\hline a Impact measured through structured & survey conducted in the year 2003. \\
Economic benefits are for multiple \\
years from 2000-2001 to 2002-2003 \\
crop seasons.
\end{tabular}




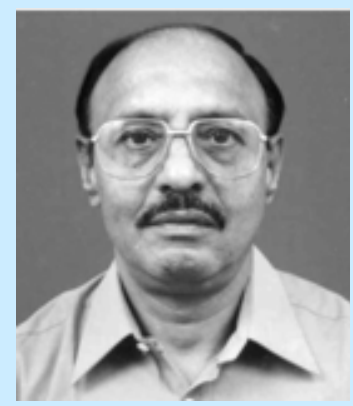

S. Pande

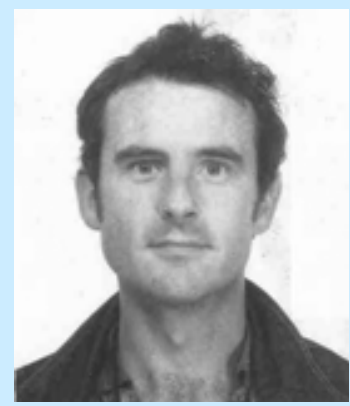

P. Stevenson

D. Grzywacz

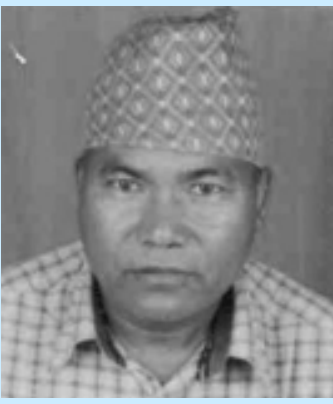

R. N. Chaudhary

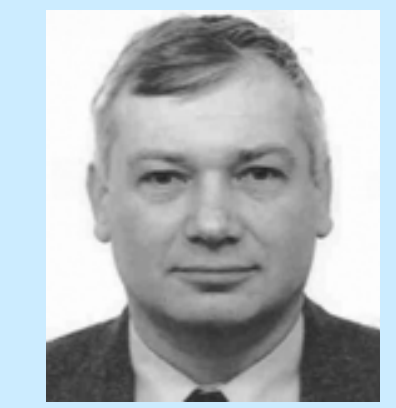

Dr. Pande is a principal scientist in the International Crops Research Institute for the Semi-Arid Tropics (ICRISAT) located at Patancheru, India, where he leads research and extension programs for management of fungal diseases of chickpea, peanut, and pigeonpea. He received his M.Sc. (1972) in plant pathology from the Himachal Agricultural University, India, and his Ph.D. (1977) from the Department of Plant Pathology at Indian Agricultural Research Institute, New Delhi. He has served as a cereal and legume pathologist for ICRISAT since 1980. He has extensive overseas experience in international agriculture research and development in plant pathology in Asia and Africa. His current research interests are epidemiology and integrated management of fungal diseases of chickpea and pigeonpea and further up-scaling of ICM of chickpea, peanut, and pigeonpea in Asia with a focus on India, Nepal, and Bangladesh.

Dr. Stevenson is a natural product chemist in Natural Resources Institute (NRI), UK. He also works at Royal Botanic Gardens, Kew, and had extensive overseas field experience in South Asia and Africa. He received his B.Sc. Hons. in applied biology from Brunel University of West London and his Ph.D. (1992) in entomology/plant chemistry from University of London. His current interests include natural resistance mechanisms of plants to insects and pathogens, biological activity of plant compounds for potential agricultural or medicinal applications, and implementation of integrated pest management for crop production by poor farmers.

Mr. Rao is a senior scientific officer in the department of plant pathology of the International Crops Research Institute for the Semi-Arid Tropics (ICRISAT) located at Patancheru, India. He received his Masters degree in plant pathology from the Andhra University, India, and joined ICRISAT as scientific officer in 1979. His research activities have focused on the epidemiology and management of economically important fungal foliar and soilborne diseases of chickpea, groundnut, and pigeonpea. His current emphasis is on promoting and disseminating integrated pest management technologies for chickpea in India, Nepal, and Bangladesh, and for peanut in India.

Mr. Neupane is the former coordinator of the national grain legumes research program for the Nepal Agricultural Research Council. He received his Masters degree in agronomy from the Kerala Agricultural University, India. He is actively involved in promotion of legume crops including chickpea, lentil, and pigeonpea in the cropping systems of Nepal, through farmer

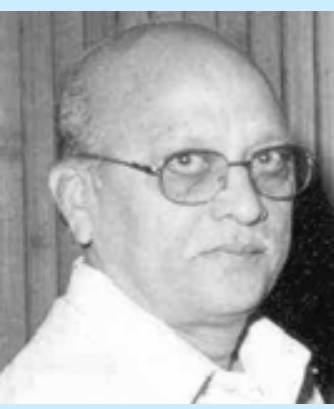

J. Narayana Rao

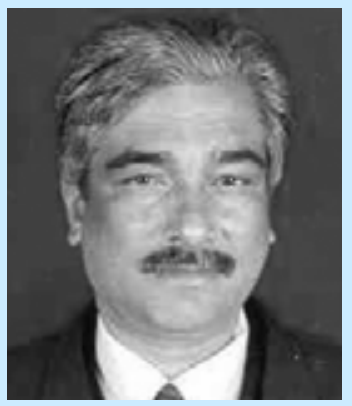

V. A. Bourai
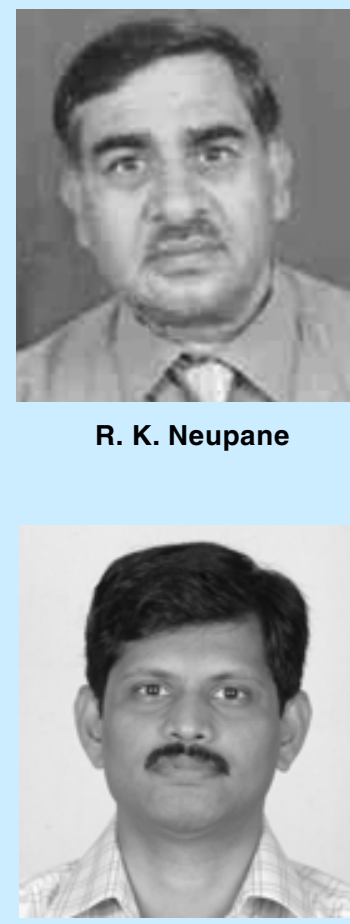

G. Krishna Kishore
R. K. Neupane

participatory research. His present research activities include large-scale promotion of legume production in the countryside of Nepal to help the country achieve sustainability in grain legumes and alleviate rural poverty.

Mr. Chaudhary is a senior scientist (plant pathology) at the national oilseed research program, Nawalpur, Sarlahi in Nepal under Nepal Agricultural Research Council. He received his Masters degree in plant pathology from the Kasetsart University, Thailand. He is actively involved in promotion of integrated pest management technology in legumes for the benefit of resourcepoor farmers. Currently, he is responsible for research activities on oilseed pathology and farmers' participatory IPM promotion in chickpea and pigeonpea.

Dr. Grzywacz is an insect pathologist and leader of microbial control and applications group of the pest management department of Natural Resources Institute (NRI), UK. He had over 20 years of experience in research and development of insect diseases for use as crop protection tools in the tropics. $\mathrm{He}$ is a specialist in production of NPV biopesticides in developing countries, quality control in biopesticides production, field trials of biopesticides in tropical agriculture, training of producers and agricultural extension staff, and regulation of biopesticides in developing countries.

Dr. Bourai is an associate professor in the department of economics of SGRR Post Graduate College of HNB University of Garhwal, Uttaranchal, India. He supervised a number of research studies on development issues related to women of the Himalayas. He has worked as consultant economist for the Department for International Development, UK, and the Canadian International Development Agency. He has worked for the empowerment and enhancement in quality of life indicators of women of the Himalayas since 1983. He has also studied the impact of upland rice varieties on the livelihood of resource-poor farmers of Eastern India.

Dr. Kishore is a visiting scientist in the department of plant pathology of the International Crops Research Institute for the Semi-Arid Tropics (ICRISAT), Patancheru, India. He began this position in 2004, soon after the completion of his Ph.D. from the Department of Plant Sciences, University of Hyderabad, India. His current research activities include integrated management of Botrytis gray mold and Ascochyta blight diseases of chickpea, and late leaf spot disease of groundnut through host plant resistance, biocontrol agents, and elicitors. He is also involved in determination of the pathogenic and molecular variability among Indian isolates of Botrytis cinerea and Ascochyta rabiei. 
levels of BGM resistance available in wild chickpea can be introgressed into cultivated lines by interspecific hybridization. Identification of effective biocontrol agents that are compatible with the existing disease and insect management strategies will further reduce the use of pesticides.

\section{Acknowledgments}

This publication is an output from a research project (R7885) funded by the Department for the International Development (DFID), UK, for the benefit of developing countries.

\section{Literature Cited}

1. Bakr, M. A., Rahman M. L., and Ahmed, A. U. 2002. Manifestation of Botrytis grey mold in chickpea in Bangladesh. Pages 63-69 in: Integrated Management of Botrytis Grey Mold of Chickpea in Bangladesh and Australia. M. A. Bakr, K. H. M. Siddique, and C. Johansen, eds. Bangladesh Agricultural Research Institute, Joydebpur, Gazipur, Bangladesh.

2. Butler, D. R. 1993. How important is crop microclimate in chickpea botrytis gray mold? Pages 7-9 in: Recent Advances in Research on Botrytis Gray Mold of Chickpea. M. P. Haware, C. L. L. Gowda, and D. McDonald, eds. International Crops Research Institute for the Semi-Arid Tropics, Patancheru 502 324, AP, India.

3. Chaurasia, P. C. P. 1998. Progress of research on Botrytis gray mold of chickpea in Nepal, 1995-97. Pages 19-21 in: Recent Advances in Research and Management of Botrytis Gray Mold of Chickpea. S. Pande, M. A. Bakr, and C. Johansen, eds. International Crops Research Institute for the Semi-Arid Tropics, Patancheru 502 324, AP, India.

4. Davidson, J. A., Pande, S., Bretag, T. W., Lindbeck, K. D., and Kishore, G. K. 2004. Biology and management of Botrytis spp. in legume crops. Pages 295-318 in: Botrytis: Biology, Pathology and Control. Y. Elad, B. Williamson, P. Tudzynski, and N. Delen, eds. Kluwer Academic Publishers, Dordrecht, The Netherlands.

5. Haware, M. P. 1998. Diseases of chickpea. Pages 473-516 in: The Pathology of Food and Pasture Legumes. D. J. Allen and J. M. Lenne, eds. CAB International, Wallingford, UK, and International Crops Research Institute for the Semi-Arid Tropics, Patancheru 502 324, AP, India.

6. Haware, M. P., and McDonald, D. 1992. Integrated management of Botrytis gray mold of chickpea. Pages 3-5 in: Botrytis Gray Mold of Chickpea. M. P. Haware, D. G. Faris, and C. L.
L. Gowda, eds. International Crops Research Institute for the Semi-Arid Tropics, Patancheru 502324 , AP, India.

7. Indian Institute of Pulses Research. 1997. Package of practices for pulse crops in India. IIPR, Kanpur 208 024, India.

8. Knights, E. J., and Siddique, K. H. M. 2002. Manifestation of Botrytis cinerea on chickpeas in Australia. Pages 70-77 in: Workshop Proceedings Integrated Management of Botrytis Grey Mould of Chickpea in Bangladesh and Australia. Bangladesh Agricultural Research Institute, Joydebpur, Gazipur, Bangladesh.

9. Laha, S. K., and Grewal, J. S. 1983. Botrytis blight of chickpea and its perpetuation through seed. Indian Phytopathol. 36:630-634.

10. Nene, Y. L., Haware, M. P., and Reddy, M. V. 1981. Chickpea diseases: Resistance-screening techniques. Information Bull. 10. International Crops Research Institute for the Semi-Arid Tropics, Patancheru 502 324, Andhra Pradesh, India.

11. Pande, S., Bourai, V. A., and Neupane, R. K. 2003. Wealth generation through chickpea revolution. On-farm IPM of chickpea in Nepal3. Information Bull. 66. International Crops Research Institute for the Semi-Arid Tropics, Patancheru 502 324, Andhra Pradesh, India.

12. Pande, S., Bourai, V. A., Neupane, R. K., and Joshi, P. K. 2003. Chickpea production constraints and promotion of Integrated Pest Management in Nepal. On-farm IPM of chickpea in Nepal-1. Information Bull. 64. International Crops Research Institute for the Semi-Arid Tropics, Patancheru 502 324, Andhra Pradesh, India.

13. Pande, S., Bourai, V. A., Stevenson, P. C., and Neupane, R. K. 2003. Empowerment Through Enrichment. On-farm IPM of Chickpea in Nepal-2. Information Bull. 65. International Crops Research Institute for the Semi-Arid Tropics, Patancheru 502 324, Andhra Pradesh, India.

14. Pande, S., Johansen, C., and Rao, J. N. 1998. Management of Botrytis gray mold of chickpea - A review. Pages 23-40 in: Recent Advances in Research and Management of Botrytis Gray Mold of Chickpea. S. Pande, M. A. Bakr, and C. Johansen. eds. International Crops Research Institute for the Semi-Arid Tropics, Patancheru 502 324, Andhra Pradesh, India.

15. Pande, S., Singh, G., Rao, J. N., Bakr, M. A., Chaurasia, P. C. P., Joshi, S., Johansen, C., Singh, S. D., Kumar, J., Rahman, M. M., and Gowda, C. L. L. 2002. Integrated management of botrytis gray mold of chickpea. Information Bull. 61. International Crops Research Institute for the Semi-Arid Tropics, Patancheru 502 324, Andhra Pradesh, India.
16. Pandey, S. P., Yadav, C. R., Sah, K., Pande, S and Joshi, P. K. 2000. Legumes in Nepal Pages 71-97 in: Legumes in the Rice and Wheat Cropping Systems of the Indo-Gangetic Plain - Constraints and Opportunities. C. Johansen, J. M. Duxbury, S. M. Virmani, C. L. L. Gowda, S. Pande, and P. K. Joshi, eds. International Crops research Institute for the Semi-Arid Tropics, Patancheru 502 324, India, Cornell University, Ithaca, NY, USA.

17. Ray, P. A., Unamma, B., and Anuebunwa, F. O. 1989. On-farm evaluation of chemical, manual, and cultural practices in integrated weed management in a yam+maize intercrop. Pages 161-167 in: On-farm Research in Theory and Practice. Proceedings of Workshop on Design and Analysis of On-farm trials, 27 February-3 March 1989. H. J. W. Mutsaers, and P. Walker, eds. International Institute for the Tropical Agriculture, Nigeria.

18. Rupela, O. P. 1990. A visual rating system for nodulation of chickpea. Int. Chickpea Newsl. 22:22-25.

19. Shahzad, M. K., and Shah, Z. A. 2003. Screening of the best insecticide in reducing the chickpea pod damage inflicted by Gram pod borer, Helicoverpa armigera (Lepidoptera: Noctuidae) in Faisalabad. Pakistan J. Biol. Sci 6:1156-1158.

20. Shreshtha, K., Joshi, S., Chaudhary, G., Chaurasia, P. C., and Adhikary, R. C. 1997 Research on Botrytis gray mold of chickpea in Nepal. Pages 19-20 in: Recent Advances in Research on Botrytis Gray Mold of Chickpea M. P. Haware, J. M. Lenne, and C. L. L. Gowda, eds. International Crops Research Institute for the Semi-Arid Tropics, Patancheru 502 324, AP, India.

21. Srivastava, S. P., Yadav, C. R., Rego, T. J., Johansen, C., and Saxena, N. P. 1997. Diagnosis and alleviation of boron deficiency causing flower and pod abortion in chickpea (Cicer arietinum L.) in Nepal. Pages 95-99 in: Boron in Soils and Plants, Proceedings of the International Symposium on Boron in Soils and Plants. R. W. Bell, and B. Rerkasem, eds. Chiang Mai, Thailand.

22. Tripathi, H. S., and Rathi, Y. P. S. 1992. Epidemiology of Botrytis gray mold of chickpea. Pages 8-9 in: Botrytis Gray Mold of Chickpea. M. P. Haware, D. G. Faris, and C. L. L. Gowda, eds. International Crops Research Institute for the Semi-Arid Tropics, Patancheru 502324 , AP, India

23. Williams, P. C., and Singh, U. 1987. Nutritional quality and the evaluation of quality in breeding programmes. Pages 329-356 in: The Chickpea. M. C. Saxena and K. B. Singh, eds. CAB International, UK, and ICARDA, Aleppo, Syria.

\section{ERRATUM}

A correction to this article was made on November 22, 2005. On the title page, the spelling of the name of the seventh author was corrected. It should read V. A. Bourai. 